\title{
Morphological Forms of Siberian Stone Pine (Pinus sibirica Du Tour) Trees in High Altitudinal Forests of the Severo-Chuisky Range. Dendrochronological Aspect
}

\author{
Svetlana A. Nikolaeva* and Dmitry A. Savchuk \\ Institute of Monitoring of Climatic \\ and Ecological Systems of the SB RAS \\ 10/3 Academichesky, Tomsk, 634055, Russia
}

Received 26.06.2015, received in revised form 25.07.2015, accepted 19.10.2015

\begin{abstract}
At the upper forest belt in the primary Siberian stone pine-Siberian larch forests in the headwater Aktru, Severo-Chuisky Range, the Altai Mountains, Russia the qualitative analysis of tree and branch radial increment was made in the main growth form (upright-trunk tree) of Siberian stone pine (Pinus sibirica Du Tour), its relatively autonomic structures (power candelabra branches and elfin wood form), and the transitional morphological ("living" stumps, "living" windfallen trees, shrub-like form, and trees with multi-storey root system) and other growth (clump-like trees) forms. The external (weather and climatic processes, geomorphological events, and phytocoenotic interactions) and the internal factors effect on initiation and existence of the morphological structures and the transitional morphological forms and their growth. The internal factors are 1) absolute and biological age of the trees, 2) primary or secondary origin of the branches, 3) degree of development of the roots, and 4) the connection between the morphological structures and the mother trunk and root. Under favourable growth conditions in the Siberian stone pine trees the form of the curve of the trunk increment is close to the bell with maximum increment in the earlier age when growth temp and acceleration are maximum in the sites. The forms of growth curves can be approximate the equations of the parabola or the exponential curves with the positive or negative accelerations as well as the horizon straight line when the growth curves become plane.
\end{abstract}

Keywords: Pinus sibirica, morphological form, living form, radial increment, tree rings, high elevation, Severo-Chuisky Range, Altai Mountains.

DOI: $10.17516 / 1997-1389-2015-8-4-459-477$.

(C) Siberian Federal University. All rights reserved

* Corresponding author E-mail address: sanikol1@rambler.ru 


\title{
Морфологические формы \\ кедра сибирского (Pinus sibirica Du Tour) \\ в высокогорных лесах Северо-Чуйского хребта. Дендрохронологический аспект
}

\author{
С.А. Николаева, Д.А. Савчук \\ Институт мониторинга климатических \\ и экологических систем СО РАН \\ Россия, 634055, Томск, пр. Академический, 10/3
}

\begin{abstract}
В верхней части лесного пояса в коренных кедровых и лиственнично-кедровых сообществах в горно-ледниковом бассейне Актру (Северо-Чуйский хребет, Центральный Алтай) у прямостоячих деревьев кедра сибирского (Pinus sibirica Du Tour) (основная жизненная форма), его относительно автономных структур (ветви-канделябры, стланиковидные образования), a также переходных морфологических и других жизненных форм («куст», «живой» пень, «живой» валежник, дерево с многоярусной корневой системой, куртинообразное дерево) проведен качественный анализ радиального прироста ствола и ветвей. Показано, что при благоприятных для роста условиях форма кривой прироста стволов близка к колоколу с максимумом прироста в более раннем возрасте. Рост ветвей особей других форм может быть представлен отдельными участками такого колокола. Эти участки могут быть аппроксимированы уравнениями параболь, экспоненты с положительным или отрицательным ускорениями, а в случае уплощчения такой кривой-уравнением прямой. Рост ксилемы через корне-листовые связи регулируется как внешними (погодно-климатические изменения, геоморфологические процессы, фитоценотические взаимодействия и т.п.), так и внутренними факторами. К последним относятся: (1) абсолютный и биологический возраст особей, (2) происхождение ветвей, (3) наличие и степень развития корней, (4) наличие связи морфологических структур с материнским стволом и корнем.
\end{abstract}

Ключевые слова: морфологическая форма, жизненная форма, радиальный прирост, лесной пояс, Северо-Чуйский хребет, Центральный Алтай, кедр сибирский, Ріпиs sibirica.

\section{Введение}

Внешний облик деревьев формируется на основе ростовых процессов. Изменения в скорости роста их разных частей происходят как при возрастном развитии, так и при воздействии разнообразных внешних факторов. Это в конечном счете приводит к изменению габитуса особи. Так, если на большей части ареала кедр сибирский представлен жизнен- ной формой прямостоячего дерева, то при приближении к верхней границе в горах у него сначала появляются новые морфологические структуры ${ }^{1}$ в пределах кроны дерева, затем переходные морфологические формы и наконец новые жизненные формы особей. В верхней части лесного пояса такие структуры и формы встречаются не часто, но их появление считается индикатором близости 
климатических границ (Хуторной и др., 2001; Горошкевич, Кустова, 2002; Тимошок и др., 2009; Николаева, Савчук, 2013а, 2014; Филимонова, 2014 и др.).

Особенности динамики радиального прироста деревьев разного биологического возраста в ареале их распространения, а тем более особей других жизненных форм на экологических границах, анализируются редко (Галазий, 1954; Колищук, 1967; Борщева, 1986; Сабиров, 1986; Laberge et al., 2001; Хуторной и др., 2001; Горошкевич, Кустова, 2002; Савчук, Николаева, 2011; и др.). Установлено, что в оптимальных для роста условиях величины радиального прироста ствола дерева изменяются с возрастом по одновершинной кривой с максимумом прироста в относительно молодом возрасте. Форму кривой прироста часто описывают уравнением параболы или экспоненты. Внешние факторы влияют на величину отклонения прироста от возрастной кривой и способны существенно изменять длину и амплитуду его колебаний. В частности, при смене ранга жизненной формы - дерева с прямостоячим стволом на дерево со стелющимся стволом - ширина годичных колец в основании ствола снижается, вплоть до их выпадения, изменяется темп их нарастания в радиальном и продольном направлениях ствола (Колищук, 1967; Битвинскас, 1974; Черкашин, Кузьмичев, 1977; Карпов, 1983; Шиятов, 1986; Полюшкин, 1987 и др.). Анализ роста таких морфологических форм может быть полезным для понимания способов их адаптации к длительным изменениям среды и климата.

Цель исследования - выявить особенности радиального роста особей кедра сибирского разных жизненных и морфологических форм в высокогорных лесах Северо-Чуйского хребта Центрального Алтая (на примере горно-ледникового бассейна Актру).

\section{Материалы и методы}

Объекты исследования - особи кедра сибирского, произрастающие в горноледниковом бассейне Актру в верхней части лесного пояса на высотах 2100-2300 м над ур. м. Район исследования расположен на северном макросклоне Северо-Чуйского хребта с абсолютными высотами до 4075 м, здесь имеется большой массив оледенения. Этот бассейн представляет собой долину с крутым западносеверо-западным и более пологим восточноюго-восточным склонами. Климат резко континентальный. Погодно-климатические условия территории характеризуются коротким вегетационным периодом, резкими перепадами сезонных и суточных температур и освещения, в том числе ультрафиолетовой радиации, высокой вероятностью заморозков и снегопадов в течение всего лета. Помимо этого на рост древесной растительности влияют геоморфологические явления (ледники, землетрясения, сели, лавины и т.п.), каменистость субстрата и несформированность почв, а также пожары.

Кедр основной жизненной формы (прямостоячее одноствольное дерево) составляет основу массивов коренных сомкнутых и разреженных лесов. Древостои этих лесов лиственнично-кедровые и кедровые, циклично-разновозрастные. Они состоят из двух-четырех основных генераций деревьев: первая в разных фитоценозах имеет средний возраст от 410 до 530 лет, вторая - 270-350, третья - 75-160 (реже 210) и четвертая, или подрост, - менее 50 лет (Тимошок и др., 2009; Бочаров, 2011 и др.). Особи кедра других морфологических форм изредка встречаются в разреженных сообществах, на полянах и по периферии сомкнутых лесных массивов, а также растут одиночно в верхней части лесного пояса (Николаева, Савчук, 2012, 2013аб, 2014). Краткая характеристика модельных 
экземпляров кедра (деревьев разных онтогенетических состояний и особей других форм) приведена в табл. 1.

Биологический возраст деревьев, т.е. их онтогенетическое состояние, оценивали по морфологическим признакам, уточненным ранее для кедра (Тимошок и др., 2009; Николаева и др., 2011).

Для получения статистически однородных и максимально длинных индивидуальных древесно-кольцевых рядов образцы древесины отбирали как можно ниже по стволу или ближе к основанию ветви. Высота взятия кернов повышалась при наличии больших сердцевинных гнилей и мощно развитых корневых лап. У взрослых прямостоячих деревьев керны брали на высоте 0,4-1,3 м (у лежащих стволов деревьев - на расстоянии 1,5-2,5 м от основания), у молодых - керны (спилы) в основании стволиков, у морфологических структур и форм - керны на расстоянии 0,1-0,4 м от основания ветви и в основании вертикального участка последней. Образцы не отбирали при (1) сильном развитии сердцевинных гни-

Таблица 1. Краткая характеристика модельных особей кедра сибирского в верхней части лесного пояса в горно-ледниковом бассейне Актру

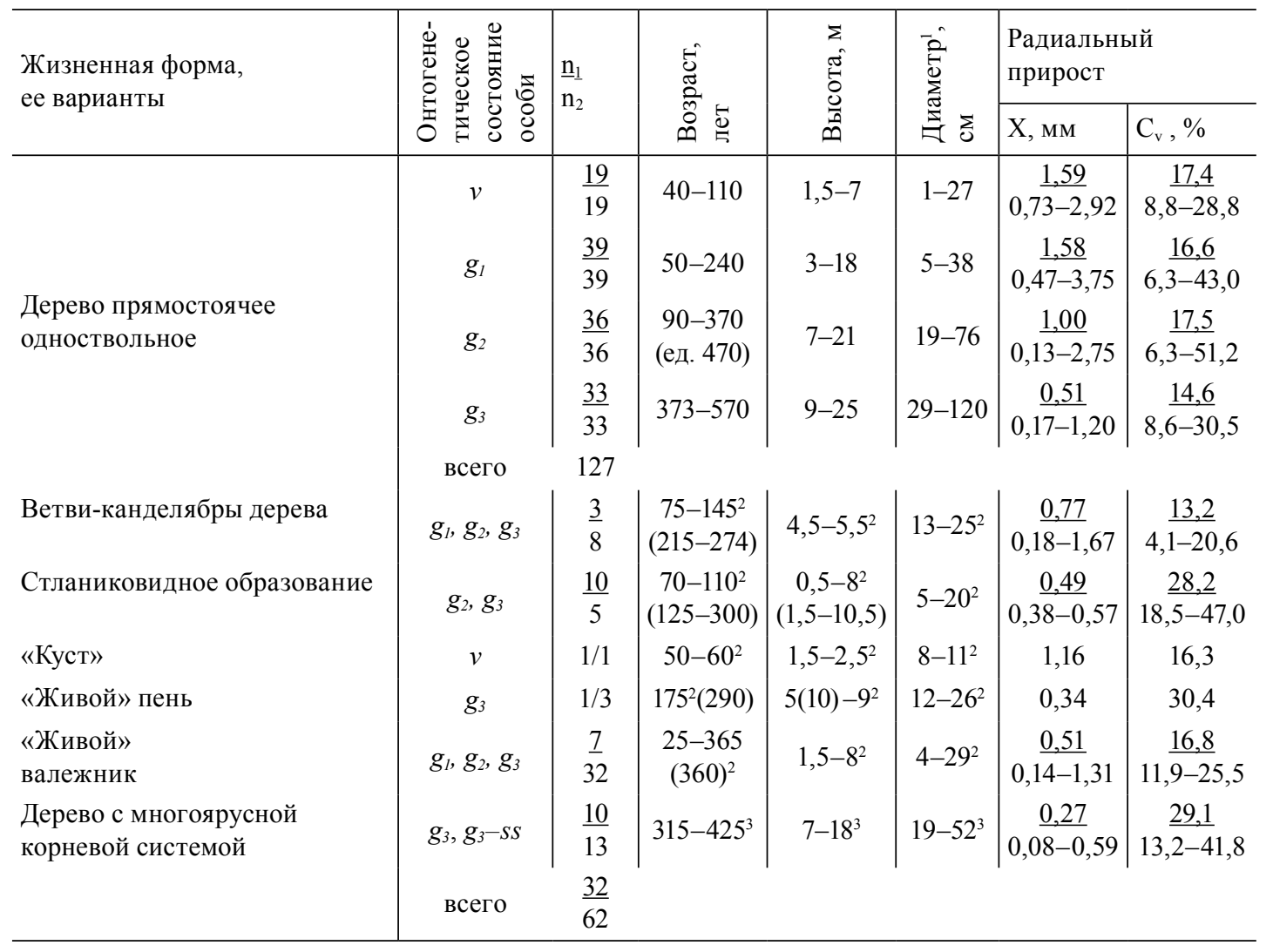

Примечание. Онтогенетическое состояние: $v$ - виргинильное, $g_{1}$ - молодое генеративное, $g_{2}$ - зрелое генеративное, $g_{3}$ - старое генеративное, $g_{3}-s s$ - переходное между старым генеративным и субсенильным («постгенеративное»).

$\mathrm{n}_{1}$ - количество модельных экземпляров, $\mathrm{n}_{2}$ - количество древесных образцов (каждый включает 2 радиуса), $\mathrm{X}$ - среднее значение прироста за последние 10 лет, $\mathrm{C}_{\mathrm{v}}$ - коэффициент вариации.

1 У деревьев диаметр дан на высоте груди, у морфологических форм - в основании ветвей-стволиков; ${ }^{2}$ у морфологических форм возраст и размеры даны для ветвей-стволов (ортотропные участки ветви), в скобках - для всей ветви с учетом плагиотропного участка; ${ }^{3}$ у деревьев с многоярусной корневой системой возраст и размеры даны без учета засыпания оснований стволов. 
лей, когда сохранялся только очень тонкий прикоровый слой ксилемы, и (2) «неудачном» пространственном расположении частей морфоструктур, затрудняющих отбор образцов без разрушения этих структур.

Ширина годичных колец на кернах и спилах измерялась по двум или четырем радиусам соответственно на измерительном комплексе LINTAB с точностью 0,01 мм. После получения индивидуальных серий проводилось их перекрестное датирование (Шиятов и др., 2000). Для каждого ствола или ветви радиусы усреднялись. Исключение представляют некоторые ветви особей морфологических форм, радиусы которых сильно различаются ходом своего прироста. При анализе динамики радиального прироста деревьев в основном учитывали два следующих показателя: скорость (абсолютная величина прироста) и ускорение (угол наклона тенденции прироста к оси абсцисс, или тренд прироста) роста.

\section{Результаты и обсуждение}

Основной жизненной формой кедра сибирского в ареале его распространения является прямостоячее одноствольное дерево. Онтогенетические состояния кедра генеративного периода в верхней части лесного пояса горно-ледникового бассейна Актру описаны ранее (Тимошок и др., 2009). У деревьев даже одного онтогенетического состояния возраст и размеры ствола сильно варьируют, что связано с разной густотой древостоев и местоположением сообществ по отношению к концам языков ледников. Но в целом с увеличением абсолютного возраста деревьев в ходе их онтогенеза прослеживается тенденция постепенного увеличения размеров ствола (табл. 1) и изменения формы кроны (Тимошок и др., 2009).

Деревья кедра разных абсолютного возраста и онтогенетического состояния наи- более полно представлены в лесном сообществе, расположенном у конечно-мореного вала ледника Малый Актру. Здесь у наиболее развитых деревьев в динамике радиального прироста ствола четко выделяется возрастной тренд (рис. 1, 1), который имеет форму колокола обычно с укороченной восходящей (левой) и удлиненной нисходящей (правой) ветвями. Низкая скорость и ускорение роста в начале жизни молодых растений (начальный отрезок кривой - рис. $1, a$ ) вызваны либо внутренними (слабое развитие корней и фотосинтетического аппарата у особей ювенильного состояния), либо внешними (фитоценотическое угнетение особей имматурного состояния деревьями верхнего полога или видами нижних ярусов) причинами.

У конкретных особей обычно фиксируется только часть такого тренда. У молодых деревьев представлена восходящая ветвь кривой с высоким ускорением роста. При этом чем ниже по стволу взят образец древесины, тем больший отрезок начала жизни особи можно проанализировать. Отрезок кривой, соответствующий началу жизни деревьев, на графиках их прироста может отсутствовать по нескольким причинам: (1) полегание стволика в первые десятилетия жизни, (2) наличие мощных корневых лап и сердцевинных гнилей, которые обычны у наиболее развитых экземпляров, (3) засыпание основания ствола обломочным материалом, (4) особенности отбора кернов (минимальная высота взятия керна буравом обычно составляет не менее 15-20 см от поверхности субстрата или наблюдается смещение сердцевины от центра ствола). Кроме того, данные, соответствующие первым годам и даже десятилетиям жизни особи, не восстанавливаются из-за сложностей с идентификацией годичных колец в нижней части стволика молодых растений (очень узкие кольца, нарастание ксилемы 


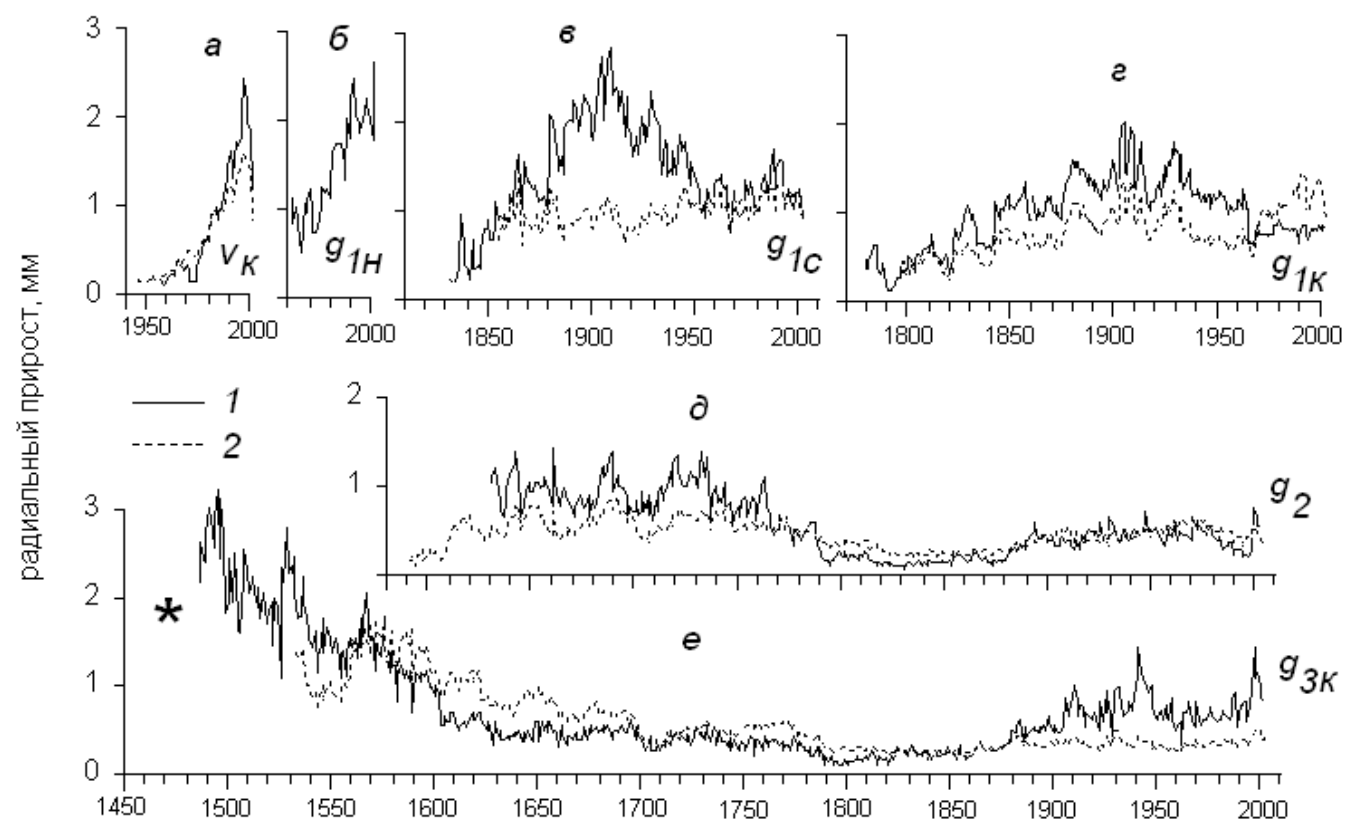

Рис. 1. Динамика радиального прироста стволов деревьев кедра сибирского в разновозрастном кедровнике в верхней части лесного пояса (горно-ледниковый бассейн Актру, Северо-Чуйский хребет, Центральный Алтай). 1 - кривая приростов наиболее развитых деревьев, 2 - средние значения прироста по группе. Онтогенетическое состояние дерева на момент обследования: $v$ - виргинильное, $g_{l}$ - молодое генеративное, $g_{2}$ - зрелое генеративное, $g_{3}$ - старое генеративное, $g_{3}-S s-$ переходное между старым генеративным и субсенильным («постгенеративное»); $\mu$ - начало, $c-$ середина, $\kappa-$ конец соответствующего состояния. * - отсутствие данных из-за сердцевинной гнили.

только по отдельным секторам кольца, нечеткие границы между соседними кольцами).

Наибольшие величины ускорения роста (угол наклона кривых) ствола характерны для деревьев виргинильного (v) состояния, когда они врастают в верхний ярус древостоя. Максимальная скорость при минимальном ускорении роста у наиболее развитых деревьев наблюдаются в конце $v$ - начале молодого генеративного $\left(g_{l}\right)$ состояний (табл. 1 , рис. $1 a-\sigma$, 1). В это время деревья уже вышли в верхний полог древостоя. Период с высокой скоростью роста (экспоненциальная, или лог-фаза) будет соответствовать периоду «большого роста» Ю. Сакса (Гольд и др., 2008 и др.). После этого начинается закономерное снижение скорости роста сначала с высоким отрицательным ускорением при нахождении деревьев в состоянии $g_{1}$, затем все с более низким у деревьев зрело- го $\left(g_{2}\right)$ и старого $\left(g_{3}\right)$ генеративных состояний (рис. 1 в-e, 1). Такое снижение в основном обусловлено внутренними причинами: ухудшением корне-листовых связей при возрастном увеличении размеров дерева и появлением новой - репродуктивной - функции у индивида и, соответственно, дополнительным оттоком пластических веществ к формирующимся шишкам (Казарян, 1969; Битвинскас, 1974; Борщева, 1986; Савчук, Николаева, 2011 и др.).

Большинство деревьев имеет более низкие значения прироста ствола по сравнению с наиболее развитыми (табл. 1). Особенно заметны различия между деревьями при сравнении их возрастных кривых в период «большого роста». У большинства деревьев возрастная кривая не выражена. В результате на графиках средних значений прироста пик, 
характерный для периода «большого роста», сильно сглажен или отсутствует (рис. $1 a, b-\partial$, 2), что, скорее всего, связано с более высокой фитоценотической конкуренцией у таких деревьев (Карпов, 1983; Сабиров, 1986; Савчук, Николаева, 2011 и др.). Аналогично изменяется прирост деревьев и в других сообществах этого бассейна.

В росте наиболее развитых деревьев фитоценотический фактор не играет заметной роли, а влияние климата усиливается. В результате дендроклиматического анализа стандартизированных рядов прироста взрослых деревьев кедра в этом районе (Бочаров, 2011 и др.) установлено, что на него влияют изменения раннелетней температуры. Анализ возрастных кривых прироста наиболее развитых деревьев показывает, что скорость их роста в период «большого роста» меняется в разные исторические периоды. В сообществах бассейна в периоды средневекового (XV-XVI вв.) и современного (с середины XIX в. по настоящее время) потепления климата прирост этих деревьев в среднем составлял 2,1 (в разных сообществах - $1,8-2,8)$ и $2,3(1,5-3,3)$ мм соответственно. В «малый ледниковый» период (XVII - середина XIX в.) он был на 30-40 \% ниже - 1,4 (0,9-2,3) мм.

Наиболее ярко эти различия проявились у деревьев разного возраста в лиственничнокедровом сообществе, расположенном у подножия конечно-моренного вала ледника Малый Актру (рис. 1). Ускорение роста на восходящей части кривой, приходящейся на потепление климата (на графиках середина XIX-XX вв.), выше, а время, необходимое для достижения максимальных значений прироста, меньше (рис. 1 a-в) по сравнению с таковой деревьев, приходящейся на период похолодания (конец XVIII - середина XIX в.) (рис. 1 г). Кроме того, прирост наиболее развитых деревьев в течение всей их жизни в пе- риоды длительного потепления значительно превышает его средние значения, а в период длительного похолодания равен или даже ниже средних значений (рис. 1).

Возраст самых старых деревьев равен 550-570 годам (Тимошок и др., 2009). У деревьев, основания которых засыпаны обломочным материалом толщиной 1,5-2 м (Николаева, Савчук, 2012, 2013б), возраст больше как минимум на 100-150 лет, т.е. он должен достигать 650-730 лет. Встречаются и более старые деревья. А.Н. Назаровым (СФУ) в этом районе найдено дерево, имеющее 826 годичных колец.

Помимо особей кедра основной жизненной формы (прямостоячее дерево), в верхней части лесного пояса горно-ледникового бассейна Актру особи переходных и других жизненных форм изредка встречаются как в коренных лесах, так и при одиночном стоянии. Их формирование, как правило, начинается после частичной гибели подземной и/ или надземной частей дерева. В зависимости от степени разрушения индивида и того, какая его часть и каким образом утрачена, восстановление его частей идет по-разному. Мы выделили четыре основных варианта, учитывающих незначительную (менее 20-30 \%) и значительную (более 70-80 \%) утрату надземных и/или подземных частей (Николаева, Савчук, 2012, 2013а, б, 2014).

I вариант - отсутствие значительных повреждений деревьев $g_{2}$ и $g_{3}$. Отдельные скелетные ветви после своей гибели часто замещаются ветвями-канделябрами (оси следующего порядка ветвления), которые морфологически хорошо выделяются в кроне дерева (рис. $2 \mathrm{~A}, a)$. Если нижние ветви укореняются, то формируется новая жизненная форма куртинообразующее дерево (рис. 2 Б, $а$ ). Скорость и ускорение роста ветвей зависит от их происхождения (первичное или вторичное) и 


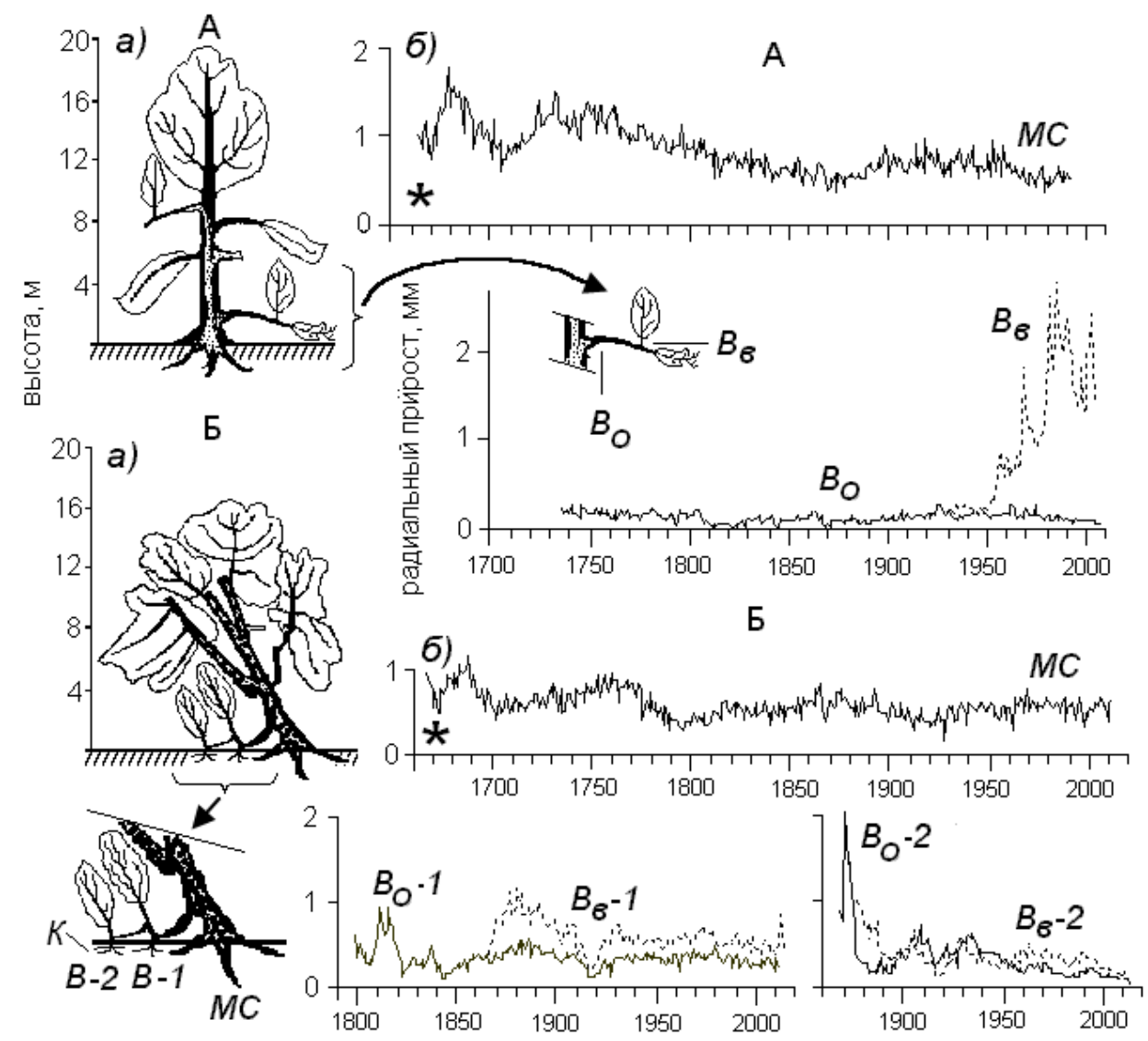

Рис. 2. Внешний вид $(a)$ и динамика радиального прироста (б) ствола и скелетных ветвей у деревьев (вариант I - объяснения вариантов в тексте). А - дерево $g_{2}$ (возраст 400 лет) с ветвями-канделябрами, Б - дерево $g_{3 \kappa}(\approx 450-500$ лет) с двумя дочерними поколениями $B-1$ и $B-2$ (куртинообразующее дерево). Условные обозначения к рис. 2-6: $M C$ - материнский ствол, $B$ - ветвь, $B_{o}$ - основание ветви, $B_{c}-$ середина ветви, $B_{6}$ - основание ортотропного участка ветви, $B-1-B-5$ - порядковый номер ветви, $K-$ корень. Остальные обозначения см. рис. 1

направления роста. Нижние скелетные ветви (оси I порядка) взрослых деревьев первичного происхождения ${ }^{2}$ имеют низкие величины прироста на протяжении всей своей жизни 0,1-0,2 мм и менее (рис. 2 А, $\sigma-B_{o}$ ), которые всегда ниже прироста ствола материнского дерева (рис. $2 \mathrm{~A}, \sigma-M C$ ). Возрастная кривая не выражена.

На этих скелетных ветвях ближе к их дистальным концам могут появляться ветви, растущие ортотропно (оси следующих порядков). Они, как правило, имеют более высокую скорость роста и разные формы кривых прироста. 1) Форма кривой может быть не выра- жена (рис. 2 Б, $\left.\sigma-B_{-}-1\right)$, т.е. у таких ветвей ускорение роста близко к нулю. 2) Прирост может быть низким в начале жизни и резко увеличивающимся в дальнейшем у ветвей вторичного происхождения (ось II порядка) т.е. иметь положительное ускорение роста (рис. $\left.2 \mathrm{~A}, \sigma-B_{6}\right)$, как у молодых деревьев ( $v$ и $g_{l}$ ) семенного происхождения (см. рис. $1, a-6$ ).

3) И, наоборот, прирост может быть высоким в начале жизни и резко снижаться в дальнейшем (рис. 2 Б, $\sigma-B_{\theta}$-2) у ветвей вторичного происхождения (оси III и IV порядка), т.е. иметь отрицательное ускорение роста. Возраст ортотропных участков таких ветвей- 
канделябров достигает 75-145 лет, а в основании самой скелетной ветви превышает 200 лет (табл. 1).

У деревьев генеративного периода от ствола между лап иногда могут отходить ветви, внешне похожие на стланик, - стланиковидные образования (рис. $3 \mathrm{~A}, a)$. У деревьев $g_{2}$ и $g_{3}$ на протяжении всего горизонтального участка такой ветви и в основании вертикального участка ксилема по радиусу нарастает медленно - 0,1-0,3 мм и менее. Например, у одной из таких изученных ветвей в основании ее горизонтального участка выпало около 50 \% годичных колец (график не приведен). При появлении придаточных корней в 2000 г. участки этой ветви, расположенные после корня по ходу ее нарастания, усилили свой прирост в 5-10 раз (рис. 3 А,
$\left.\sigma-B_{c}, B_{s}\right)$. Эта ветвь как стланиковидное образование существует с начала XVIII в., т.е. около 300 лет.

У более молодых деревьев $\left(g_{l}\right)$ скорость роста горизонтальных участков таких ветвей в несколько раз выше (до 1,0-1,5 мм) по сравнению с вышеописанной у более старых $\left(g_{2}\right.$ и $\left.g_{3}\right)$, но ниже таковой ствола собственного материнского дерева (рис. 3 Б, $\sigma-B_{o}$ и $M C$ соответственно). Вертикальные участки таких структур способны к дальнейшему развитию с формированием относительно самостоятельных стволов-деревьев высотой 7-8 м с собственной корневой системой (рис. 3 Б, $a-$ $B-1)$. Эту особь можно отнести к новой жизненной форме (куртинообразующее дерево). Возраст такой ветви составляет около 130 лет.
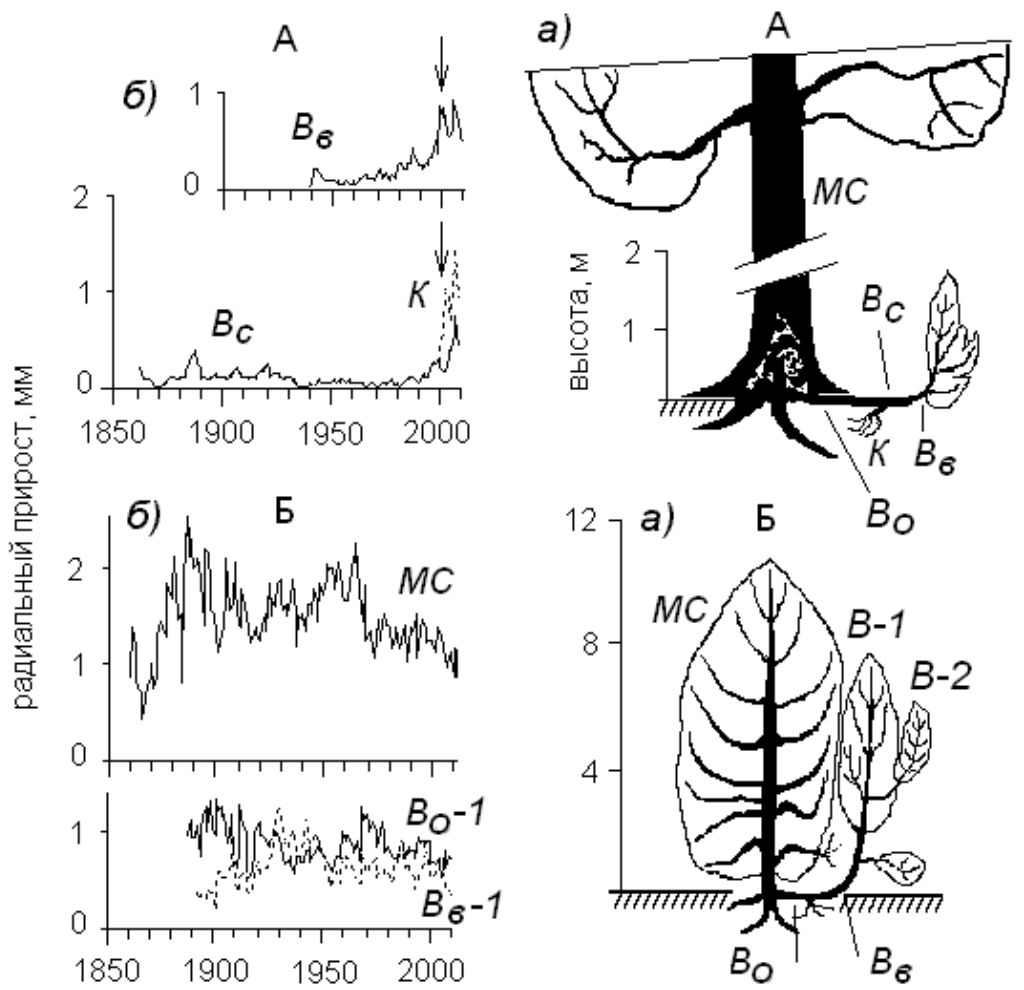

Рис. 3. Внешний вид (a) и динамика радиального прироста (б) деревьев со стланиковидными образованиями в основании ствола (вариант I). А -дерево $g_{2}\left(400\right.$ лет), Б $-g_{l}$ (170 лет). Стрелками показан год появления корня. Остальные обозначения см. рис. 1 и 2 
При анализе роста особей кедра других морфологических форм, которые начинают формироваться после частичной гибели надземных и/или подземных частей деревьев, мы учитывали следующее. Неблагоприятные или резко изменяющиеся условия для функционирования фотосинтетического аппарата и корней деревьев или гибель некоторой их части независимо от того, какими причинами это было вызвано (увеличение возраста, фитоценотическая конкуренция, лимитирующие значения факторов среды, рубки, объедание листвы вредителями, засыпание деревьев обломочным материалом и т.п.), снижают прирост ксилемы их ствола (Казарян, 1969; Романова, Судачкова, 1990; Борщева, 1986; Бех, Николаева, 2008; Демидко и др., 2009; Николаева, Савчук, 2012, 2013б; Колтунов, 2012 и др.). Поэтому такое снижение прироста ствола и ветвей особей кедра других морфологических форм при прочих равных условиях мы использовали для датировки времени гибели надземных и подземных частей дерева.

II вариант - гибель 70-80 \% кроны и ствола дерева при отсутствии значительных повреждений корневой системы. Восстановление утраченных надземных частей у деревьев кедра $v$ и $g_{l}$ небольшого размера за счет разрастания первичных ветвей приводит к образованию особи кустовидной формы (рис. 4 $\mathrm{A}, a)$. Например, у обследованной особи такие ветви, подобно нижним скелетным ветвям генеративных деревьев (рис. 2 А, $\sigma-B_{o}$ ), первоначально росли медленно (0,1-0,3 мм), а после засыхания верхней части ствола и кроны в 1993 г. они резко увеличили свой прирост до 1-2 мм и более (рис. 4 А, б). В новом качестве эта особь существует уже 20 лет.

У деревьев $g_{2}$ и $g_{3}$ после гибели верхней части ствола восстановление утраченных элементов кроны идет за счет развития вторичных ветвей, которые имеют вид канделябра. В результате образуется такая форма, как «живой» пень. Так, у одной из особей древесина пня почти полностью сгнила, за исключением очень тонкого прикорового слоя. От пня в месте, где сохранился сук от первичной ветви, отходит вторичная ветвь $B-1$ (ось II порядка), от основания которой, в свою очередь, отходит следующая вторичная ветвь $B-2$ (ось
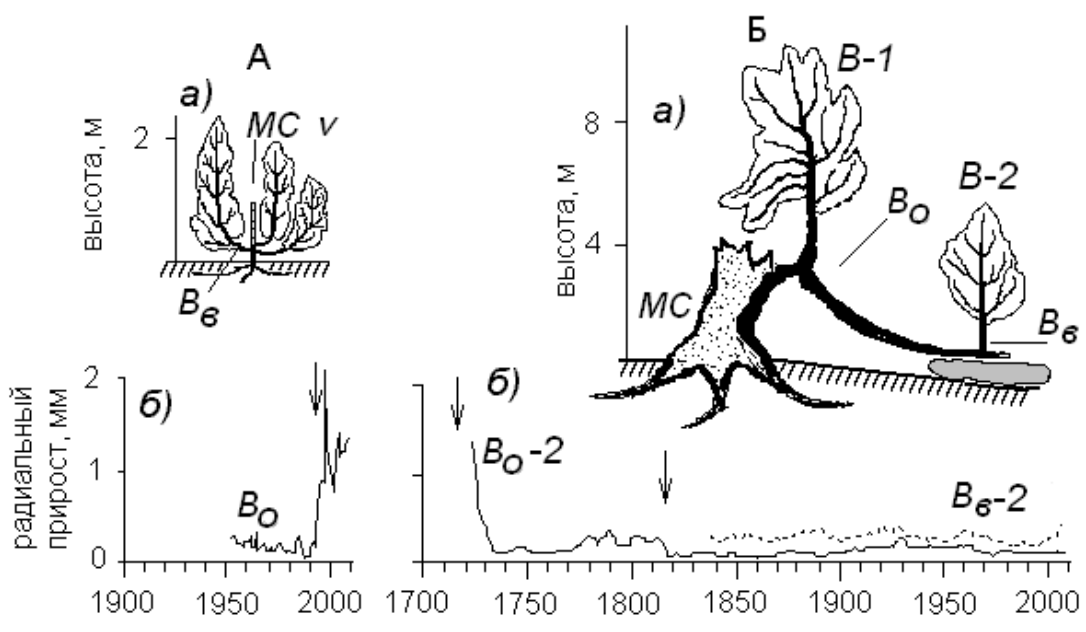

Рис. 4. Внешний вид (a) и динамика радиального прироста (б) кустовидного образования (А) и «живого» пня (Б) (вариант II). А - особь $v$ (65 лет), Б - $g_{3}-S s$ ( $\approx 550-600$ лет). Стрелками показаны годы начала формирования новой формы. Остальные обозначения см. рис. 1 и 2 
III порядка) (рис. 4 Б, $а$ ). Последняя ветвь $B-2$, не укоренившаяся из-за наличия валуна, возрастом 290 лет, большую часть жизни имеет низкую скорость роста в основании как всей ветви (менее 0,1-0,2 мм), так и ее ортотропного участка $\left(0,2-0,5\right.$ мм) (рис. 4 Б, $\left.\sigma-B_{o}-2, B_{6}-2\right)$. Форма кривой прироста в основании этой ветви сходна с таковой у вторичной ветвидерева куртинообразующего дерева (рис. 2 Б, $\left.\sigma-B_{o}-2, B_{6}-2\right)$. Мы предполагаем, что на фоне похолодания климата в начале XIX в. произошло окончательное разрушение (к 1816 г.) большей части ствола и кроны этого дерева, в результате чего прирост в основании этой ветви снизился с 0,3 до 0,1 мм, а особь приобрела вид «живого» пня. И в этом качестве она существует около 190 лет.

III вариант. Гибель 70-80 \% надземной и подземной частей дерева наблюдается после вывала деревьев верхнего яруса. В результате в почве сохраняется один-два скелетных корня, а в надземной части - бо́льшая часть ствола и ветви, расположенные на морфологически верхней поверхности полулежащего или полностью лежащего ствола. Начинает развиваться новая морфологическая форма «живой» валежник (рис. 5 a). Лежащий ствол может нести от одной (имеет состояние $g_{2}$ или $g_{3}$ ) до десяти (состояния $v, g_{l}$ ) живых ветвей.

Например, одно из таких деревьев было сбито при падении на него соседнего дерева в 1938 г. В это время оно было молодым $\left(g_{l}\right)$ и его возраст составлял 82 года. Ствол материнского дерева 68 лет находится в полулежащем положении. Его четыре молодые первичные ветви, возраст трех из которых в момент падения материнского ствола составлял 1-8 лет, быстро перешли к ортотропному росту в новом направлении (рис. $5 \mathrm{~A}, a$ ). Максимальная скорость (2-3 мм) роста таких ветвей (рис. $5 \mathrm{~A}$, $\left.\sigma-B_{\theta}-1, B_{\theta}-3\right)$ близка к таковой стволов хорошо растущих молодых деревьев $v$ и $g_{l}$ (рис. $1 a-8$ ), но величина ускорения таких ветвей выше, а время необходимое для достижения максимальной скорости роста, меньше.

Более старые деревья кедра из-за наличия обширных гнилей ствола обычно вываливаются сами. Так, одно такое дерево упало в 1789 г. в возрасте 230 лет и состоянии $g_{2}$. В настоящее время на нем имеется пять ветвей разного внешнего вида: от ветвей $g_{3}$ около обломанной вершины до ветвей $g_{2}$ на расстоянии 3,3 м от основания материнского ствола. Тяж ксилемы ствола соединяет эти ветви с материнским корнем (рис. 5 Б, а). Эта морфологическая форма существует уже 219 лет. Часть его ветвей сохранила направление роста, близкое к исходному, и низкую скорость роста. Это первичные ветви $(B-2, B-5)$, имеющие внешний вид $g_{3}$. Часть ветвей изменила направление роста на новое ортотропное. Это вторичные ветви $(B-1, B-3, B-4)$, имеющие внешний вид $g_{2}$. У них более высокая скорость роста по сравнению с первичными. Одна из этих ветвей несколько десятилетий назад укоренилась и превратилась в ветвьдерево с собственной корневой системой $\left(B_{g^{-}}\right.$ 1, ось III порядка). Появление корней в 1965 г. прекратило возрастное снижение прироста в последние десятилетия по сравнению с остальными ветвями, не имеющими корней (рис. 5 Б, $\sigma-B_{6}-1$ и $B_{o}-2, B_{6}-3$ соответственно). Эта ветвь-дерево соединена с материнским стволом горизонтальным участком (остатки вторичной скелетной ветви - ось II порядка), на спиле которого по изменению величины и направления прироста ксилемы четко диагностируется время падения дерева (рис. 5 Б, $\left.6-B_{o}-1\right)$.

Нами обнаружена особь, представляющая собой «живой» полегший пень. Она в своем развитии прошла минимум три стадии: обычное дерево с ветвями-канделябрами, после гибели верхней части кроны - «живой» 


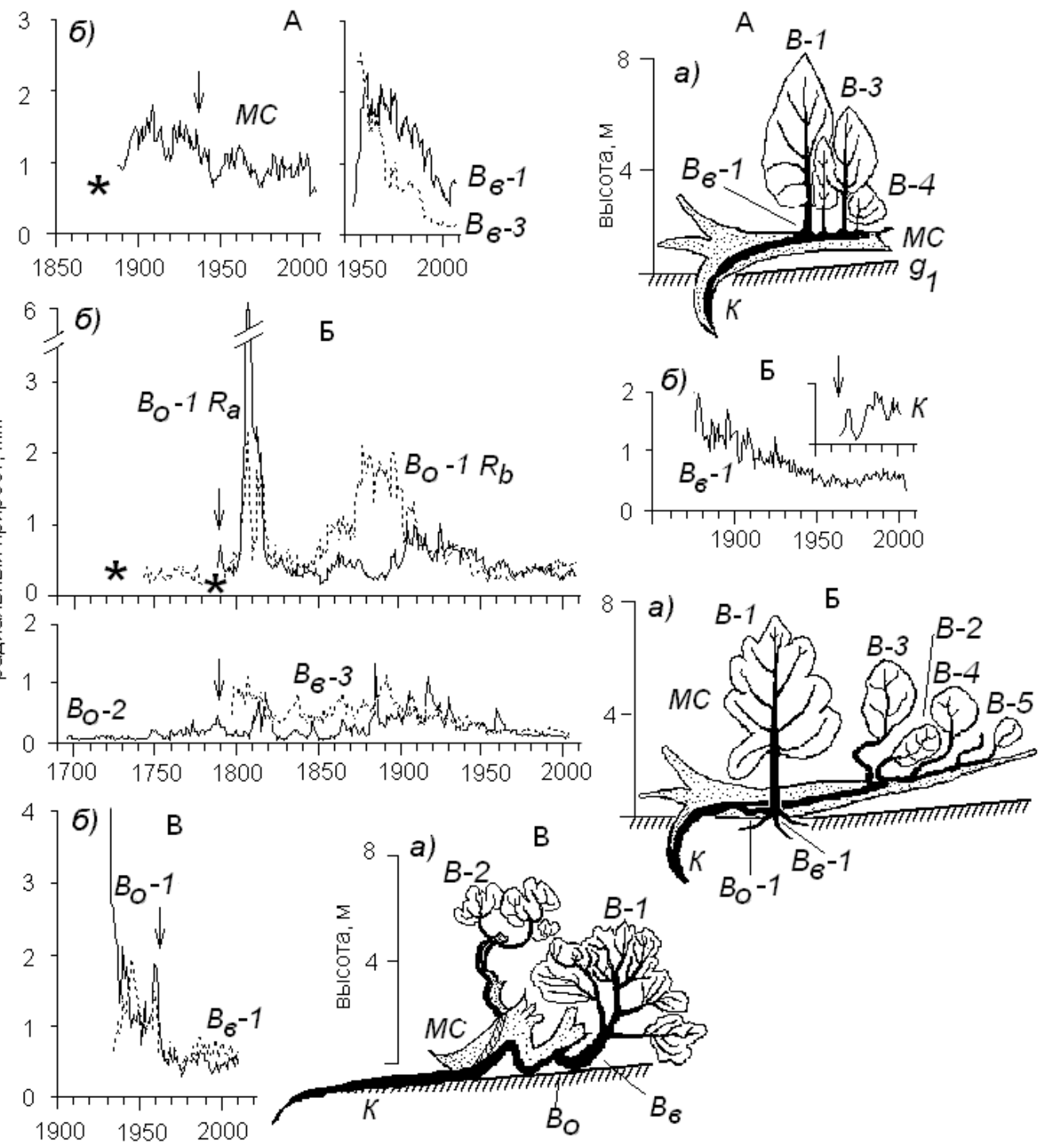

Рис. 5. Внешний вид $(a)$ и динамика радиального прироста (б) «живого» валежника (вариант III). $\mathrm{A}$-особь $g_{l}\left(150\right.$ лет), Б - $g_{2}$ (450 лет), В $-g_{3}-s s\left(\approx 600-700\right.$ лет). $\mathrm{R}_{\mathrm{a}}$ и $\mathrm{R}_{\mathrm{b}}-$ два наибольших по длине взаимно перпендикулярных радиуса. Остальные обозначения см. рис. 1 и 2

пень с ветвями-канделябрами, а после его падения - «живой» валежник с двумя мощными ветвями-канделябрами и одним очень длинным скелетным корнем (рис. 5 В, a). Прирост одной из двух ее вторичных ветвей (ось III порядка) характеризуется высокими значениями (2-4 мм) вначале и резким снижением в дальнейшем (рис. $5 \mathrm{~B}, \sigma-B_{o}-1, B_{s}-1$ ). Такая форма ее кривой сходна с таковой вторичной ветви (ось III порядка) «живого» пня (рис. 4 Б, б -
$\left.B_{o}-2\right)$ и дочерних ветвей-деревьев (оси III и IV порядка) куртинообразующего дерева (рис. 2 Б, $\left.\sigma-B_{o}-2, B_{s}-2\right)$. Предположительно этот пень вывалился в 1963 г., когда резко изменился ход роста по разным радиусам в основании сохранившейся ветви $B_{o}-1$. В новом качестве эта особь существует 51 год.

IV вариант. Гибель 70-80 \% корневой системы дерева при отсутствии значительных повреждений надземной части 
осуществляется при засыпании оснований стволов обломочным материалом в областях его массового перемещения. Придаточные корни таких деревьев восстанавливаются на стволе в новых приповерхностных слоях субстрата. При неоднократных засыпаниях корневая система из поверхностно-якорной становится многоярусной (рис. $6 \mathrm{~A}, a)$. Прирост ствола одного такого дерева на уровне современной почвы характеризуется невы- сокими значениями (до 1 мм) на протяжении 300 лет (рис. 6 А, б, 2). В XVIII в. выявлены многочисленные выпавшие (около 50 \% колец за столетие до 18 колец подряд по одному из радиусов) кольца. Возрастная кривая не выражена. Прирост ствола на глубине 1,2 м имеет возрастной тренд, характерный для молодых деревьев, с максимальной величиной около 2 мм. Этот участок ствола перестал расти в толщину к 1707 г.
A
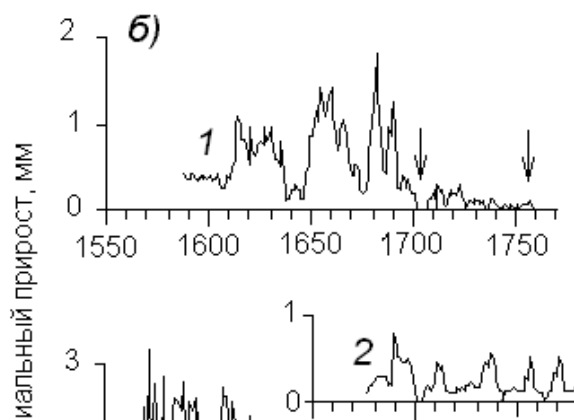

$1700 \quad 1750$

E

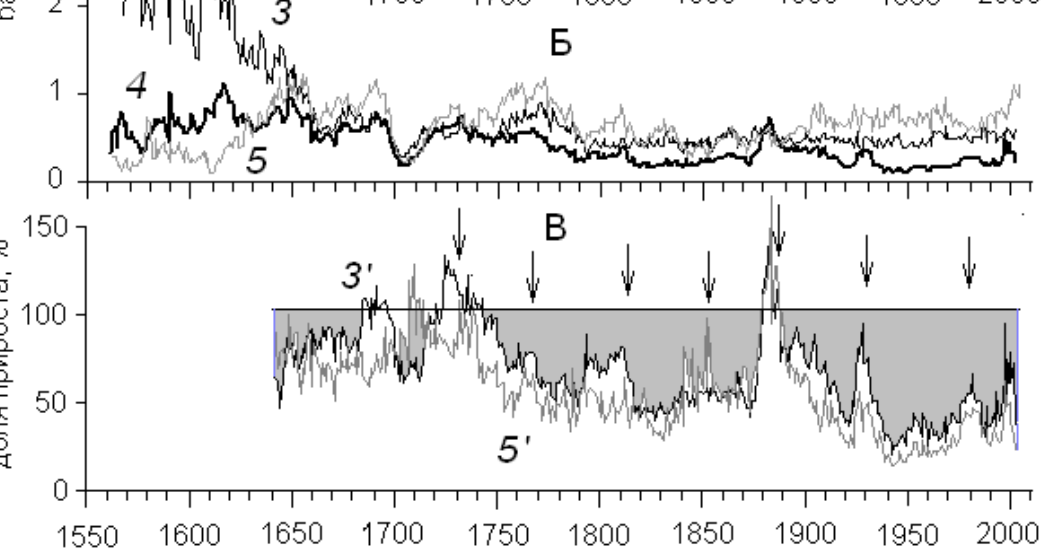

Рис. 6. Внешний вид (a) и динамика радиального прироста (б) деревьев с многоярусной корневой системой (IV вариант). A - дерево $g_{3}-S S$ (460 лет), около которого сделан почвенный разрез, растущее по периферии лесного массива за конечно-моренным валом ледника Малый Актру, Б - деревья $g_{3}(450-$ 500 лет) из двух лесных массивов, В - относительный прирост засыпанных деревьев по сравнению с незасыпанными, \%. Условные обозначения: 1 - керн взят на глубине 1,2 м и 2 - на высоте 0,17 м от современного уровня почвы, 3 - деревья, растущие в лесном массиве за конечно-моренным валом ледника Малый Актру $(\mathrm{n}=3), 4$ - засыпанные деревья, растущее по периферии этого же массива $(\mathrm{n}=10)$, 5 - деревья, растущие в лесном массиве на морене ледника Большой Актру (n=9). 3', 5'- относительный прирост засыпанных деревьев по отношению к незасыпанным из массивов 3 и 5 соответственно. Стрелками показаны годы окончания роста засыпанной части ствола (А) и начала циклических снижений прироста (B). Остальные обозначения см. рис. 1 и 2

$$
-471-
$$


по одному и к 1758 г. по другому радиусу (рис. $6 \mathrm{~A}, 6,1)$.

Ствол этого дерева обследован до глубины 1,8 м. Вся толща субстрата сложена мелко- и среднеобломочным материалом. Разница в количестве годичных колец ствола у поверхности почвы и на глубине 1,2 м составляет 88 колец, а на глубине 1,8 м должна быть еще больше. По неопубликованным данным М.Ф. Адаменко, толщина засыпания деревьев, произрастающих у подножия конечно-моренного вала ледника Малый Актру (зона частых засыпаний), достигает 3-5 м. Поэтому при определении возраста таких деревьев возможна потеря 100-150 и более лет.

Радиальный прирост засыпанных деревьев ниже, чем незасыпанных, но синхронность между ними сохраняется (рис. 6 Б). Для того чтобы в колебаниях прироста выявить составляющую, связанную с засыпаниями, и нивелировать климатическую, прирост засыпанных деревьев представлен в относительных единицах по отношению к незасыпанным (рис. 6 В). Эта кривая, полученная нами ранее для пяти живых деревьев (Николаева, Савчук, 2012, 2013б), была дополнена данными по ширине годичных колец еще пяти произраставших рядом засохших деревьев. Полученный относительный прирост засыпанных деревьев представляет собой циклические снижения и подъемы со средней продолжительностью 40 (от 36 до 45) лет, начало которых после 1758 г. приходится на 1769, 1814, 1850, 1888, 1932 , 1970 гг. (рис. 6 В).

Таким образом, возрастные кривые прироста стволов и нижних скелетных ветвей деревьев, а также ветвей, появившихся взамен утраченных надземных частей, имеют разную форму. Возрастная кривая в виде колокола или его части реализуется в приросте стволов наиболее развитых деревьев, у угнетенных деревьев она уплощается, принимая в крайних случаях вид горизонтальной прямой (жизненная форма - прямостоячее дерево). Форму прироста ветвей также можно представить в виде отдельных частей колокола, особенно у других жизненных и морфологических форм (I-III варианты). Разные участки такой кривой можно аппроксимировать уравнениями параболы, экспоненты с положительным или отрицательным ускорениями, а в случае уплощения такой кривой - в виде горизонтальной прямой.

Форму прироста нижних скелетных ветвей (оси I порядка) чаще можно представить в виде горизонтальной прямой с низкой или близкой к нулевой скоростью и ускорением роста (рис. $2 \mathrm{~A}, \sigma-B_{o}$ ) или промежуточного варианта между прямой и колоколом (рис. 2 Б, $\left.\sigma-B_{o}-1, B_{s}-1\right)$. Такой слабый рост нижних ветвей обусловлен тем, что он подавляется вышерасположенными элементами кроны, т.е. он подчиняется закономерностям апикального доминирования, которые реализуются у деревьев как целостных биосистем (Казарян, 1969; Горошкевич, Велисевич, 1996 и др.). Экспоненциальное увеличение скорости роста наблюдается у ветвей при снятии условий для такого апикального доминирования, т.е. при гибели концов скелетных ветвей (осей предыдущего порядка ветвления), вышерасположенных ветвей (рис. $2 \mathrm{~A}, \sigma-B_{s}$ ) и верхней части ствола и кроны дерева (рис. 4 $\left.\mathrm{A}, \sigma-B_{o}\right)$, а также при появлении корней у стланиковидных образований (рис. 3 А, $\sigma-$ $\left.B_{b}, B_{c}\right)$.

Экспоненциальное снижение скорости роста наблюдается у ветвей (оси III-IV порядка) особей других морфологических и жизненных форм («живой» пень, «живой» валежник, куртинообразующее дерево), имеющих первичное (рис. 2 Б, $\sigma-B_{o}-2, B_{\theta^{-}}$ 
2) и вторичное (рис. 4 Б, $\sigma-B_{o}-2$, рис. 5 Б, $\sigma-B_{-}-1$, рис. $\left.5 \mathrm{~B}, \sigma-B_{0}-1\right)$ происхождение. Первоначально высокие значения скорости роста таких структур (ортотропно растущие ветви, ветви-деревца с собственной корневой системой), по-видимому, вызваны двумя условиями, сложившимися к началу роста ветви: относительным обособлением этих структур в кроне и высокой корнеобеспеченностью за счет связи с мощным корнем материнского дерева. Дальнейшее замедление роста таких ветвей можно объяснить существенным увеличением размеров их надземной части при сохранении тех же размеров подземной части материнского дерева. Другими словами, произошло ухудшение корне-листовых связей (Казарян, 1969; Битвинскас, 1974; Горошкевич, Велисевич, 1996 и др.), что привело к снижению прироста стволов этих структур. Образование собственных корней замедляет дальнейшее падение скорости роста: отрицательное ускорение роста сменяется на нулевое (рис. 5 Б, $\left.\sigma-B_{6}-1\right)$. Кроме того, сохранение механической связи таких морфологических структур с материнским деревом увеличивает их устойчивость, поскольку собственные корни не могут обеспечить ее из-за их незначительных размеров по сравнению с надземной частью.

Форма кривой радиального прироста засыпанных деревьев мало отличается от таковой незасыпанных (морфологическая форма IV вариант). Но для относительного прироста стволов таких деревьев характерны циклические колебания длительностью около 40 лет. Это, скорее всего, связано с циклами гибели корней в результате их засыпания обломочным материалом и затем их восстановления на стволе в приповерхностных слоях субстрата на новых высотных уровнях (Николаева, Савчук, 2012, $2013 б$ и др.).

\section{Заключение}

В верхней части лесного пояса в горноледниковом бассейне Актру (Северо-Чуйский хребет, Центральный Алтай) основной жизненной формой кедра сибирского является прямостоячее одноствольное дерево. Здесь также встречаются деревья с относительно автономными морфологическими структурами в кроне (ветви-канделябры, стланиковидные образования у деревьев) и особи переходных и других жизненных форм («куст», «живой» пень, «живой» валежник, дерево с многоярусной корневой системой, куртинообразующее дерево). Продолжительность жизни деревьев кедра достигает 570-730 лет, в отдельных случаях - более 800 лет. Время существования морфологических структур на момент обследования равнялось 75-300 годам, переходных и других жизненных форм - 20220 годам. Наибольшая продолжительность существования оказалась у стланиковидных образований в основании деревьев (300 лет) и «живого» валежника (220 лет).

Возрастная кривая радиального прироста, имеющая вид колокола с укороченной восходящей и удлиненной нисходящей ветвями, реализуется у деревьев, находящихся в относительно благоприятных для роста условиях. При этом наибольшие величины ускорения, а затем и скорости роста достигаются у деревьев виргинильного и молодого генеративного состояний. Форма этой кривой уплощается в неоптимальных для роста условиях, принимая в крайне неблагоприятных случаях вид горизонтальной прямой. Рост стволов и нижних скелетных ветвей деревьев, а также ветвей, появившихся взамен утраченных при повреждении надземных частей, в зависимости от конкретных условий, сложившихся к моменту начала роста, реализуется в виде разных по форме возрастных кривых, которые можно представить в виде отдельных 
участков колокола. Последние аппроксимируются уравнениями параболы, экспоненты с положительным или отрицательным ускорениями, а в случае уплощения такой кривой уравнением прямой. Относительный рост стволов деревьев, у которых периодически повреждается подземная часть (корни), представляет собой циклические колебания прироста, постепенно снижающиеся к моменту их гибели.

Рост ксилемы кедра регулируется корне-листовыми связями, т.е. соотношением фитомассы его кроны и корней. Это соотношение изменяется под влиянием как внешних (погодно-климатические изменения, геоморфологические процессы, фитоценотические взаимодействия и т.п.), так и внутренних факторов. К последним относятся: (1) абсолютный и биологический возраст особей, (2) происхождение ветвей первичное или вторичное, (3) наличие и степень развития корней - укоренение ветвей, гибель и появление корней на новых высотных уровнях ствола, (4) наличие связи морфологических структур с материнским стволом и корнем.

Дальнейшие исследования в этой области могут быть связаны с более детальным анализом радиального прироста кедра сибирского разных жизненных и морфологических форм в плане выявления различных составляющих (биологической, климатической, геоморфологической и т.п.) в динамике прироста этих форм.

\footnotetext{
Морфологически обособленные структуры - морфологические единицы в составе материнской особи с собственной иерархической структурой систем ветвления и собственным полюсом апикального доминирования, т.е. такие структуры являются относительно автономными.

2 Ветви, имеющие первичное происхождение, появляются из регулярных почек возобновления, вторичное - из латентных почек через некоторое время. Происхождение ветвей (первичное или вторичное) устанавливали по наличию разницы в возрасте скелетных ветвей и участка материнского ствола рядом с этими ветвями.

3 Система ветвления ветвей вторичного происхождения формируется за счет последовательной пролиферации самых проксимальных латентных почек. Со временем место отхождения побегов последующих генераций погружается в толщу ксилемы (Горошкевич, Велисевич, 1996). Морфологический порядок ветвления таких ветвей восстановить сложно, а в полевых условиях (без уничтожения таких ветвей) невозможно. Поэтому порядком ветвления каждой последующей оси ветвей описываемых морфологических структур условно приняли их видимый порядок.
}

\section{Список литературы}

Бех И.А., Николаева С.А. (2008) Оценка жизненного состояния кедрового подроста, освобожденного из-под полога лиственных пород. Лесное хозяйство, 5: 21-23 [Bekh I.A., Nikolaeva S.A. (2008) Assessment of vitality of Siberian stone pine seedlings released under deciduous tree canopy. Forestry [Lesnoe khoziaistvo], 6: 21-23 (in Russian)]

Битвинскас Т.T. (1974) Дендроклиматические исследования. Л., Гидрометеоиздат, 172 с. [Bitvinskas T.T. (1974) Dendroclimatic studies. Leningrad, Hydrometeoizdat, 172 p. (in Russian)]

Борщева Н.M. (1986) Влияние биологических и климатических факторов на радиальный прирост ели Шренка. Дендрохронология и дендроклиматология. Новосибирск, Наука, c. 71-76 [Borscheva N.M. (1986) Effect of biological and climatic factors on radial increment in Schrenk's spruce. Dendrochronology and Dendroclimatology. Novosibirsk: Nauka, p. 71-76 (in Russian)]

Бочаров А.Ю. (2011) Структура и динамика высокогорных лесов Северо-Чуйского хребта (Горный Алтай) в условиях изменений климата. Вестник Томского государственного универсиmema, 352: 203-206 [Bocharov A.Yu. (2011) Structure and dynamics of high altitudinal forests in the 
Severo-Chuisky Range (the Altai Mountains) under climate change. Tomsk State University Journal [Vestnik TomGU], 352: 203-206 (in Russian)]

Велисевич С.Н. (2007) О продолжительности жизни Pinus sibirica (Pinaceae). Ботанический журнал, 92 (6): 877-884 [Velisevich S.N. (2007) On life longevity in Pinus sibirica (Pinaceae). Botanical journal [Botanicheskii zhurnal], 92 (6): 877-884 (in Russian)]

Галазий Г.И. (1954) Вертикальный предел древесной растительности в горах Восточной Сибири и его динамика. Труды Ботанического института АН СССР. Серия геоботаника, 9: 210-329 [Galaziy G.I. (1954) Vertical limit of woody vegetation in mountains of East Siberia and its dynamics. Proceedings of Botanical Institute AS USSR. Series Geobotany, 9: 210-329 (in Russian)]

Гольд В.М., Гаевский Н.А., Голованова Т.И., Белоног Н.П., Горбанева Т.Б. (2008) Физиология растений. Версия 1.0 [Электронный ресурс] Красноярск, ИПК СФУ. http://files.lib.sfukras.ru/ebibl/umkd/165/u_lectures.pdf [Gold V.M., Gaevsky N.A., Golovanova T.I., Belonog N.P., Gorbaneva T.B. (2008) Physiology of plants. Version 1.0. Krasnoyarsk, SFU. http://files.lib.sfu-kras. ru/ebibl/umkd/165/u_lectures.pdf (in Russian)]

Горошкевич С.Н., Велисевич С.Н. (1996) Структура и развитие элементов вторичной кроны кедра сибирского. Онтогенез, 27 (1): 53-61 [Goroshkevich S.N., Velisevich S.N. (1996) Structure and development of elements of secondary crown in Siberian stone pine. Ontogenez, 27 (1): 53-61 (in Russian)]

Демидко Д.А., Кривец С.А., Бисирова Э.М. (2010) Связь радиального прироста и жизненного состояния у деревьев кедра сибирского. Вестник Томского государственного университета. Биология, 4 (12): 68-80 [Demidko D.A., Krivets S.A., Bisirova E.M. (2010) Relation between radial growth and vitality in Siberian stone pine trees. Tomsk State University Journal. Biology [Vestnik TomGU. Biologiia], 4 (12): 68-80 (in Russian)]

Казарян В.О. (1969) Старение высших растений. М., Наука, 312 с. [Kazaryan V.O. (1969) Aging the higher plants. Moscow, Nauka, 312 p. (in Russian)]

Карпов В.Г. (1983) Синэкологический анализ борьбы за существование в биогеоценозах еловых лесов. Чтения памяти академика В.Н. Сукачева. 1: Вопросы лесной генетики и фитоценологии. М., Наука, с. 32-74 [Karpov V.G. (1983) Synecological analysis of struggle for survival in biogeocoenosis of spruce forests. Reading in memory of V.N. Sukachev. 1: Issues of forest genetics and phytocoenology. Moscow, Nauka, p. 32-74 (in Russian)]

Колищук В.Г. (1967) Методика исследования динамики прироста стлаников на примере горной сосны Pinus mughus Scop. Ботанический журнал, 52 (6): 852-859 [Kolishchuk V.G. (1967) Method of study of the increment dynamics in elfin woods (Pinus mughus Scop. as an example). Botanical journal [Botanicheskii zhurnal], 52 (6): 852-859 (in Russian)]

Колтунов Е.В. (2012) Дендрохронологические аспекты реакции древостоев на абиотический стресс как фактора популяционной динамики в очагах массового размножения насекомыхфитофагов. Журнал СФУ. Биология, 5 (1): 13-26 [Koltunov E.V. (2012) Dendrochronological aspects of stands reaction on the abiotic stress as the populations dynamics factor at the insects-phytophagous outbreaks. J. Sib. Fed. Univ., Biol., 5 (1): 13-26 (in Russian)]

Николаева С.А., Велисевич С.Н., Савчук Д.А. (2011) Онтогенез Pinus sibirica на юго-востоке Западно-Сибирской равнины. Журнал СФУ. Биология, 4 (1): 3-12 [Nikolaeva S.A., Velisevich S.N., 
Savchuk D.A. (2011) Ontogeny of Siberian stone pine (Pinus sibirica Du Tour) in southeastern West Siberian Plain. J. Sib. Fed. Univ., Biol., 4 (1): 3-12 (in Russian)]

Николаева С.А., Савчук Д.А. (2012) Корневая система и рост кедра сибирского (Pinus sibirica Du Tour) в зоне засыпания обломочным материалом. Мир науки, культуры, образования, 4 (35): 318-322 [Nikolaeva S.A., Savchuk D.A. (2012) Root system and growth in Siberian stone pine (Pinus sibirica Du Tour) after covering with debris. The world of science, culture and education [Mir nauki, kul'tury, obrazovaniia], 4 (35): 318-322 (in Russian)]

Николаева С.А., Савчук Д.А. (2013a) Морфологические формы кедра сибирского в высокогорных лесах Северо-Чуйского хребта: 1. Морфологический аспект. Вестник Томского государственного университета. Биология, 2 (22): 101-114 [Nikolaeva S.A., Savchuk D.A. (2013a) Morphological forms of Siberian stone pine trees (Pinus sibirica Du Tour) in high altitudinal forests of Severo-Chuisky Range: 1. Morphological aspect. Tomsk State University Journal. Biology [Vestnik TomGU. Biologiia], 2 (22): 101-114 (in Russian)]

Николаева С.А., Савчук Д.А. (2013б) Кедр сибирский как индикатор обвально-осыпных процессов на Северо-Чуйском хребте. Интегращия ботанических исследований и образования: традиции и перспективы. Томск, Изд-во ТГУ, с. 137-144 [Nikolaeva S.A., Savchuk D.A. (2013b) Siberian stone pine as an indicator of geomorphological events in the Severo-Chuisky Range. Integration of botanical investigations and education: Traditions and outlooks. Tomsk State University, p. 137-144 (in Russian)]

Николаева С.А., Савчук Д.А. (2014) К систематизации морфологических форм кедра сибирского (Pinus sibirica Du Tour) в высокогорных лесах. Вестник Алтайского государственного аграрного университета, 2 (112): 64-69 [Nikolaeva S.A., Savchuk D.A. (2014) On systematization of Siberian stone pine (Pinus sibirica Du Tour) morphological forms in high mountain forests. Bulletin of Altai State Agricultural University. Biology [Vestnik AGU. Bioilogiia], 2 (112): 64-69 (in Russian)]

Полюшкин Ю.В. (1987) Индикация функциональных типов геосистем методами дендрохронологии. Дендрохронологические методы в лесоведении и экологическом прогнозировании. Иркутск, с. 57-59 [Polyushkin Yu.V. (1987) Indication of functional geosystems types by dendrochronological methods. Dendrochronological methods in forest science and ecological forecast. Irkutsk, p. 57-59 (in Russian)]

Романова Л.И., Судачкова Н.Е. (1990) Влияние дефолиации на уровень углеводов и структуру годичного кольца сосны обыкновенной. Лесоведение, 2: 54-61 [Romanova L.I., Sudachkova N.E. (1990) Effect of defoliation on carbohydrate level and tree ring structure in Scots pine. Forestry studies [Lesovedenie], 2: 54-61 (in Russian)]

Сабиров Р.Н. (1986) Дендроклиматический анализ радиального прироста лесообразующих хвойных видов Южного Приморья. Дендрохронология и дендроклиматология. Новосибирск, Наука, с. 102-108 [Sabirov R.N. (1986) Dendroclimatic analysis of radial increment of forest-forming coniferous trees in Southern Primorye. Dendrochronology and Dendroclimatology. Novosibirsk, Nauka, p. 102-108 (in Russian)]

Савчук Д., Николаева С. (2011) Рост и плодоношение кедра сибирского: Временная изменчивость и взаимосвязь. Saarbrucken, Lambert Acad. Publ., 226 с. [Savchuk D.A., Nikolaeva S.A. (2011) Growth and cone production in Siberian stone pine. Temporal variability and relationship. Saarbrucken, Lambert Acad. Publ., 226 p. (in Russian)]

$$
-476-
$$


Тимошок Е.Е., Николаева С.А., Скороходов С.Н., Савчук Д.А., Бочаров А.Ю. (2009) Ocoбенности онтогенетических состояний генеративного периода Pinus sibirica (Pinaceae) в лесах Центрального Алтая. Растительные ресурсы, 45 (1): 3-12 [Timoshok E.E., Nikolaeva S.A., Skorokhodov S.N., Savchuk D.A., Bocharov A.Yu. (2009) Peculiarities of ontogenetic stages within generative period of Pinus sibirica (Pinaceae) in forests of the Central Altai. Rastitelnye Resursy, 45 (1): 3-12 (in Russian)]

Филимонова Е.О. (2014) Структура насаждений кедра сибирского (Pinus sibirica Du Tour) в лесотундровом экотоне Северо-Чуйского хребта (Центральный Алтай): Автореф. дисс. ... канд. биол. наук. Томск, 23 с. [Filimonova E.O. (2014) Structure of Siberian stone pine (Pinus sibirica Du Tour) stands at forest-tundra ecotone in Severo-Chuisky Range (the central Altai Mountains). Autoreferat of dissertation ... candidate of biological sciences. Tomsk, 23 p. (in Russian)]

Черкашин В.П., Кузьмичев В.В. (1977) Статистический анализ рядов ширины годичныхх колеи деревьев. Красноярск, ИЛиД СО АН СССР, 50 с. [Cherkashin V.P., Kuzmichev V.V. (1977) Statistical analysis of tree ring width series. Krasnoyarsk, IFW SB AS USSR, 50 p. (in Russian)]

Шиятов С.Г. (1986) Дендрохронология верхней гранищы леса на Урале. М., Наука, 136 с. [Shiyatov S.G. (1986) Dendrochronology of upper forest limit in the Urals. Moscow, Nauka, 136 p. (in Russian)]

Шиятов С.Г., Ваганов Е.А., Кирдянов А.В., Круглов В.Б., Мазепа В.С., Наурзбаев М.М., Хантемиров Р.М. (2000) Методы дендрохронологии. Ч.1. Основы дендрохронологии. Сбор и получение древесно-кольцевой информации. Красноярск, КрасГУ, 80 с. [Shiyatov S.G., Vaganov E.F., Kirdyanov A.V., Kruglov V.B., Mazepa V.S., Naurzbaev M.M., Hantemirov R.M. Methods of dendrochronology. Isssue 1. Basics of dendrochronology. Collection of tree ring information. Krasnoyarsk, KSU, 80 p. (in Russian)]

Goroshkevich S.N., Kustova E.A. (2002) Morphogenesis of the procumbent life form in Siberian stone pine at the timberline in the Western Sayan Mountains. Russian Journal of Ecology, 33 (4): $225-230$

Khutornoi O.V., Velisevich S.N., Vorob'ev V.N. (2001) Ecological variation in the morphological structure of the crown in Siberian stone pine at the timberline. Russian Journal of Ecology, 32 (6): 393-399

Laberge M.-J., Payette S., Pitre N. (2001) Development of stunted black spruce (Picea montana) clones in the subarctic environment: A dendroarchitectural analysis. Ecoscience, 8 (4): 489-498. 